\title{
Molecular profiling and anti-infective potency of endophytic actinomycetes inhabiting Madhuca insignis Radlk., from Western Ghats of India
}

\author{
Soma Mondal and V. Ravishankar Rai
}

\begin{abstract}
Background: Endophytic actinomycetes are well known for their diverse bioactive entities and considered as an important source for drug development research.

Results: We isolated and identified four potential endophytic Streptomyces species, i.e., Streptomyces misionensis MI22, Streptomyces roietensis MI24, Streptomyces glaucescens MI29, and Streptomyces sp. MI04 inhabiting Madhuca insignis by its characteristic morphological features and $16 \mathrm{~S}$ rRNA gene sequence analysis. S. misionensis MI22 exhibits a broad spectrum of anti-microbial activity against methicillin-resistant Staphylococcus aureus (25.00 \pm 1.00 $\mathrm{mm}$ ) followed by Bacillus subtilis (23.66 $\pm 0.57 \mathrm{~mm})$, Escherichia coli $(22.00 \pm 0.00 \mathrm{~mm})$, and Candida albicans (18.00 $\pm 0.00 \mathrm{~mm}$ ). Minimum inhibitory concentrations of the ethyl acetate fraction of S. misionensis MI22 against test pathogens were ranged from 25 to $100 \mu \mathrm{g} / \mathrm{mL}$. Indeed, strain MI22 also exhibited significant anti-proliferative activity against HeLa cell line with $I C_{50}$ value $98 \mu \mathrm{g} / \mathrm{mL}$ and showed no cytotoxicity effect to the normal human embryonic kidney cell line in the MTT assay. The anti-microbial metabolites from strain MI22 were detected at $R_{f}$ 0.55 as depicted by the inhibition zone on the intensive band in TLC-bioautography assay.

Conclusion: The study indicates that, anti-microbial metabolites of these endophytic Streptomyces species, especially S. misionensis MI22 as a prolific source to discover novel bioactive metabolites to combat multidrugresistant pathogens.
\end{abstract}

Keywords: Endophytic actinomycetes, Streptomyces, Madhuca insignis, Drug discovery, Anti-microbial activity, TLC bioautography

\section{Background}

In the last few decades, more than 30 new infectious diseases have been emerged ranging from the rotavirus to Middle East respiratory syndrome coronavirus $[1,2]$. The increasing people movement across diverse borders, the rapid expansion of air traffic and human population have modified the ecosystem has made these new pathogens can easily spread all over the globe. Therefore, the hunt for new potential drugs

* Correspondence: raivittal@gmail.com

Department of Studies in Microbiology, University of Mysore,

Manasagangotri, Mysuru, Karnataka 570006, India has always been essential throughout human history to combat infectious diseases.

Natural products or secondary metabolites originate from plants, bacteria, marine, and fungal sources are the most successful source of potent lead natural drugs [3]. They serve as a continuing potent source of novel bioactive agents, retaining an immense impact on modern medicine [4]. Antibiotic drugs like erythromycin, methicillin, and penicillin are used in a great extent to treat various diseases, but currently turning to be less potent as a result of many microbes become resistant to certain antibiotics [5]. The 
right solution to cover the problem of drug-resistant pathogens is to explore and discover new biomolecules.

Microbes are considered as a potent source of natural products as evidenced by the discovery of Penicillin from the fungus Penicillium rubens by Alexander Fleming in 1928 [6]. They have the ability to biosynthesize novel compounds that can be used for medical and agricultural applications [7, 8]. Indeed, plants with ethnomedicinal values are the potent sources of broad-spectrum bioactive agents. Microbial endophytes associated with medical plants play a vital role in secondary metabolism pathways and increase the ability to produce natural metabolites [9-11]. The endophytic actinomycetes constitute one of the fascinating groups of microbes associated with a wide range of medicinal plants. They are considered as a group of actinobacteria bearing the capacity to synthesize new bioactive secondary metabolites [12]. Biological diversity, species richness, and species distribution of endophytic actinomycetes are significantly influenced by ecological environs [13]. The endophytic actinomycetes diversity and anti-microbial activity inhabiting medicinal plants of the tropical region have been reported in the earlier studies [14-16], but the plants from Western Ghats region in India has not gained research attention.

The genus Streptomyces is known for a diverse array of bioactive agents like anti-cancer, antimicrobial, anti-infective biomolecules, and other pharmaceutical important drugs [17-21]. They are considered as prolific producers of diverse bioactive agents like antioxidants, antibiotics, enzyme inhibitors, and other biomolecules having therapeutic importance [22]. Most of the endophytic actinomycetes that have been exhibited anti-microbial potential belong to the Streptomyces genus, indicating that this particular genus is of great interest to discover novel antimicrobial drugs [23-25]. Hence, there is a need to explore actinomycetes diversity for bioactive metabolites.

Madhuca insignis is a riparian tree that belongs to the Sapotaceae family which is mainly distributed in Karnataka and Kerala states of South India [26-30]. It is a critically endangered and endemic riparian species found in the Western Ghats of India. Several reports are also documented on the pharmacological applications of Madhuca species [31]. There are no reports available in search of endophytic actinomycetes from M. insignis, despite its medicinal value. Hence, this study was designed to explore endophytic actinomycetes inhabiting $M$. insignis and to evaluate their antimicrobial and anti-proliferative potential against human pathogens.

\section{Methods}

\section{Selection of plant and study site characteristics}

Leaf, stem, and root samples of $M$. insignis were collected from Agumbe $\left(13.5027^{\circ} \mathrm{N}, 75.0903^{\circ} \mathrm{E}\right)$, Western Ghats of India for the isolation of endophytic actinomycetes. The collected plant tissue samples were sealed using parafilm to keep its endophytic nature and brought to the laboratory within $24 \mathrm{~h}$ for the isolation of endophytes.

\section{Surface sterilization and isolation}

Leaves, roots, and stem samples were first rinsed in running tap water and then with double-distilled water [25]. To get rid of surface microorganisms, samples were washed with $0.1 \%$ Tween 20 for $1 \mathrm{~min}$ and washed with $75 \%$ ethanol for $5 \mathrm{~min}$. The samples were rinsed with $2 \%$ sodium hypochlorite for $5 \mathrm{~min}$, and rinsed with $10 \%$ sodium bicarbonate for $5 \mathrm{~min}$ to inhibit the growth of fungi. Later, all samples were washed with doubledistilled water and kept for surface drying. The plant tissue materials were cut into tiny segments $(5 \mathrm{~mm})$ and placed on starch casein agar (HiMedia, India) and incubated at $30{ }^{\circ} \mathrm{C}$ for 1 month. To confirm, the effect of the surface sterilization process, final wash aliquots of the sterile distilled was involuted on the culture plates. Petri plates were constantly checked for endophytic actinomycetes growth. The actinomycetes isolates were observed under the light microscope and scanning electron microscope. The morphological features like spiral sporophores, filamentous nature, hyphe, and Gram-straining were analyzed.

\section{Molecular identification of endophytic actinomycetes Genomic DNA extraction, taxon sampling, and phylogenetic affiliation}

To isolate genomic DNA, the endophytic actinomycete isolates were cultured in International Streptomyces Project-2 (ISP-2) broth for 7 days at $28{ }^{\circ} \mathrm{C}$. DNA extraction was carried out following the standard protocol [32]. The amplification of the 16s rRNA gene was carried by a PCR method using universal primers, 27F (5'-AGAGTTTGATCMTGGCTCAG-3') and 1492R (5' TACGGYTACCTTGTTACGACTT-3') [33]. PCR conditions: denaturation $95{ }^{\circ} \mathrm{C}$ for 5 min followed by 35 cycles at $95{ }^{\circ} \mathrm{C}$ for $1 \mathrm{~min}$; annealing $54{ }^{\circ} \mathrm{C}$ for $1 \mathrm{~min}$; extension $72{ }^{\circ} \mathrm{C}$ for $1 \mathrm{~min}$, final extension at $72{ }^{\circ} \mathrm{C}$ for 10 min and cooling at $4{ }^{\circ} \mathrm{C}$. The amplified PCR products were visualized in gel electrophoresis. 16S rRNA gene sequence was carried out in ABI 3730 Genetic Analyzer (Applied Biosystems, USA). The nucleotide sequences of endophytic actinomycetes with similar identities were retrieved from the National Center of Biotechnology Information (NCBI) database using BLAST search. The multiple sequence alignment was carried out using 
CLUSTAL Omega and the dendrogram was generated using MEGA 5.1 software [34].

\section{Extraction of secondary metabolites}

The endophytic actinomycetes were cultured in $1 \mathrm{~L} \mathrm{Er-}$ lenmeyer flasks with $300 \mathrm{~mL}$ of ISP-4 broth and incubated at $28{ }^{\circ} \mathrm{C}$ for 1 month under static conditions. The mycelium and filtrate of culture broth were filtered to separate each other. The filtrate was blended thoroughly and centrifuged at $5000 \mathrm{rpm}$ for $15 \mathrm{~min}$. Ethyl acetate $(\mathrm{v} / \mathrm{v})$ was used to extract the liquid supernatant and evaporated to dryness at $45{ }^{\circ} \mathrm{C}$ using a rotary flash evaporator [35].

\section{Anti-microbial activity}

Disc diffusion assay [36] was used to determine the antimicrobial activity of the ethyl acetate extract of endophytic actinomycetes against Bacillus subtilis (MTCC 121), Methicillin-resistant Staphylococcus aureus (ATCC 33915) and Escherichia coli (MTCC 7410), and Candida albicans (MTCC 183). Sterile discs were impregnated with $20 \mu \mathrm{L}$ of extracts were placed on the medium seeded with test pathogens. Negative control of sterile disc with $20 \mu \mathrm{L}$ of ethyl acetate was also impregnated for each test microbial pathogen with gentamicin (10 $\mu \mathrm{g} / \mathrm{disc})$ and nystatin $(100 \mu$ nits/disc $)$ as a positive control. Plates were then incubated for $24 \mathrm{~h}$ at $37 \pm 2{ }^{\circ} \mathrm{C}$ and $28 \pm 2{ }^{\circ} \mathrm{C}$ for bacteria and fungi, respectively [37]. The statistical analysis was carried out using IBM SPSS version (2018) software.

\section{Determination of minimum inhibitory concentration}

The ethyl acetate extract of strain MI22 was evaluated for minimum inhibition concentration by 96 -well plate method [34]. Test pathogens were cultured in sterile broth, and added to all well plates $(10 \mu \mathrm{L}$ each). The crude extract was tested in two-fold dilution (200$0.3906 \mu \mathrm{g} / \mathrm{mL}$ ). Microbial growth indicators, 2,3,5-triphenyl tetrazolium chloride (for bacteria) and 3-(4,5-dimethylthiazol-2-yl)-2,5-diphenyl tetrazolium bromide (for fungi) were added to the each well. The plates were incubated for $37 \pm 2{ }^{\circ} \mathrm{C}$ and $28 \pm 2{ }^{\circ} \mathrm{C}$ for test bacteria and fungi, respectively. The lowest concentration of the extract with no microbial growth was determined as MIC.

\section{Thin-layer chromatography-bioautography}

Anti-bacterial activity of strain MI22 was examined by thin-layer chromatography bioautographic method [38]. Ethyl acetate extract $(10 \mu \mathrm{L})$ was spotted on the surface of TLC silica gel sheet and dipped in an optimum solvent system (petroleum ether/ethyl acetate 1:2). TLC chromatogram was dried and sterilized under UV light for $20 \mathrm{~min}$. TLC chromatogram was carefully placed in a
Petri plate containing brain heart infusion agar medium with $0.8 \%$ agar incorporated with TTC and MRSA pathogen. After $2 \mathrm{~h}$ of diffusion at $8{ }^{\circ} \mathrm{C}$, Petri plate was incubated at $37^{\circ} \mathrm{C}$ for $24 \mathrm{~h}$.

\section{Anti-proliferative activity}

Anti-proliferative activity of ethyl acetate fraction of strain MI22 was carried out on HeLa cell line by MTT assay [39]. Cytotoxicity of strain MI22 extract was also carried out on normal human embryonic kidney cell line (HEK 293T; a specific cell line originally derived from human embryonic kidney cells). Dulbecco's modified eagle medium (DMEM) with $10 \%$ FBS, $100 \mathrm{mg} / \mathrm{L}$ penicillin, $250 \mathrm{mg} \mathrm{L}$ streptomycin, $2 \mathrm{mM}$ glutamine was used to culture cells and incubated at $37 \pm 2{ }^{\circ} \mathrm{C}$ with $5 \% \mathrm{CO}_{2}$. Different concentrations of ethyl acetate fraction of strain MI22 (range 10 to $200 \mu \mathrm{g} / \mathrm{mL}$ ) were added to wells. After $48 \mathrm{~h}, 10 \mu \mathrm{L}$ of MTT $(0.5 \mathrm{mg} / \mathrm{mL})$ was added to all wells and incubated for $2 \mathrm{~h}$ at $37 \pm 2{ }^{\circ} \mathrm{C}$. The medium solution in PBS was removed, $100 \mu \mathrm{L}$ of DMSO was added to all wells and $60 \mu \mathrm{M}$ of curcumin (SigmaAldrich, India) was used as a positive control. The absorbance was determined by ELISA reader at $595 \mathrm{~nm}$.

\section{Results}

\section{Isolation of endophytic actinomycetes}

Isolation of endophytic actinomycetes was carried out from bark, root, and leaf tissues of M. insignis. The culture plates which showed actinomycetes growth were picked and four profusely grown endophytic actinomycetes were selected for further studies (Fig. 1). None of the colonies came out from the last wash of the sterilization process proving that the tissue surface sterilization was effective and isolates were true endophytes.

\section{Morphological, cultural, and phenotypic characteristics of endophytic actinomycetes}

The morphological features of endophytic strains MI22, strain MI04, strain MI24, and strain MI29 cultured on actinomycetes isolation agar (AIA), starch casein agar (SCA), and International Streptomyces Project- 2 (ISP-2) media were analyzed. The growth pigment of all strains in the beginning appears to be whitish color in all media, however later differs with whitish powdery, creamy white and light brown colors. All selected strains exhibited melanin constitution which is a primary characteristic feature of Streptomyces sp.

The morphological characteristics of strain MI22 cultured on the SCA medium for 15 days were those typically exhibited by the genus Streptomyces (Fig. 1c). The strain MI22 showed typical morphology of Streptomyces with well-developed aerial mycelium and moderately grown substrate mycelium. The colonies had a 


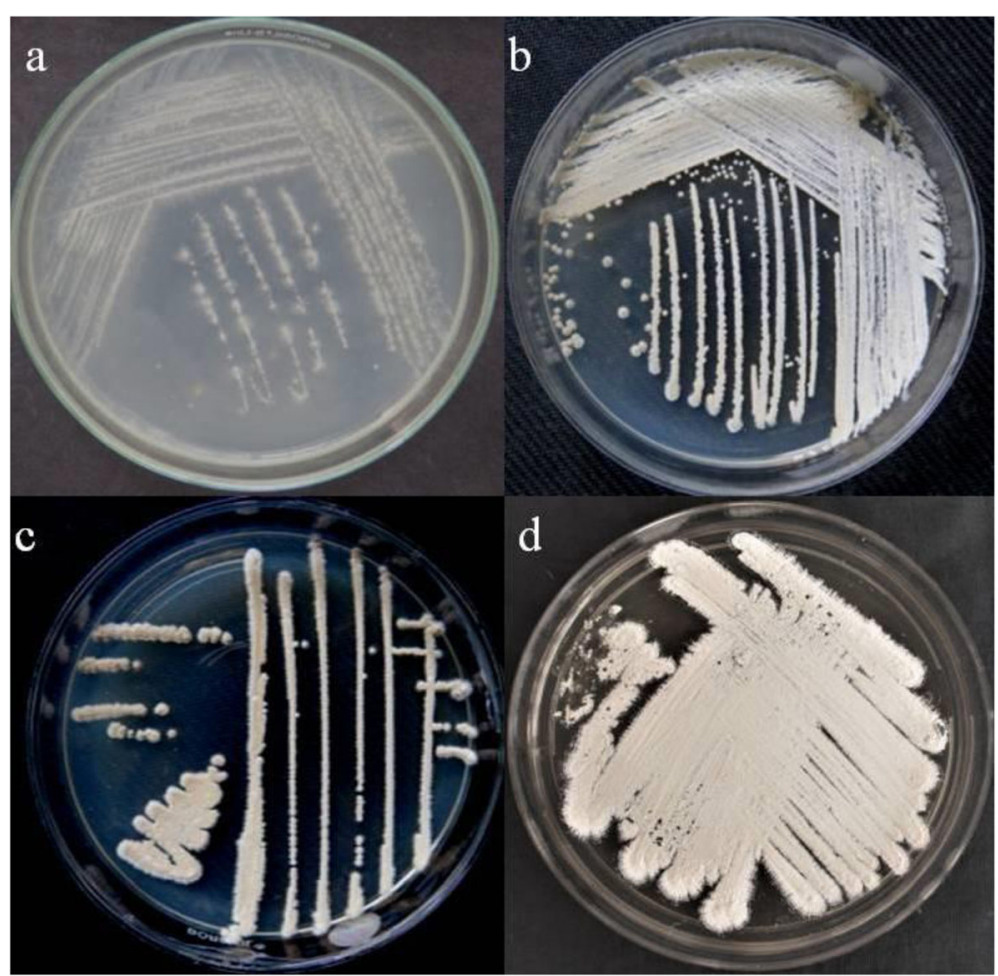

Fig. 1 a Streptomyces sp. MI04. b Streptomyces roietensis MI24. c Streptomyces misionensis MI22. d Streptomyces glaucescens MI29

convex structure, wavy periphery, and root striations. The fragmented mycelia formed straight spores with a smooth surface, light brown color as well as white powdery and smooth continuous spore ornamentation morphology.

The strain MI04 cultured on ISP-2 medium for 15 days were those typically exhibited by the genus Streptomyces (Fig. 2). The strain MI04 showed white brown rough colonies, spores-straight, wavy, or helical chain morphology characters with well-developed mycelium. The colonies are the convex structure with a wavy periphery and straight spores.

Morphological characteristics of the strain MI24 (Fig. 1b) showed Streptomyces morphology with welldeveloped substrate mycelium and aerial mycelium was formed moderately on SCA medium. The fragmented mycelium formed straight spores with a smooth surface, white powdery, and a light yellowish pigment was produced in nutrient agar medium.

The strain MI29 cultured on AIA medium colonies were white powdery, straight spores, wavy, or helical chains with a plain surface, light brown in color and smooth spore, continuous ornamentation morphology as Streptomyces sp. with matured aerial mycelium and moderately developed substrate mycelium (Fig. 1d).

\section{Molecular identification and phylogenetic affiliation}

To confirm the reliability of morphological identification, the endophytic actinomycetes strains were subjected to $16 \mathrm{~S}$ rRNA gene sequence analysis. The obtained sequences were aligned with different strains of similar 16S rRNA sequences retrieved from the NCBI database. The consensus DNA sequences in BLASTN search and phylogenic analysis suggested that the isolates were identified as Streptomyces misionensis strain MI22, Streptomyces roietensis strain MI24, Streptomyces glaucescens strain MI29 and Streptomyces sp. strain MI04. The multiple sequence alignment that was performed using Clustal Omega retrieved from the NCBI database showed in several closely resembled sequences. A phylogenetic evaluation with related members of the genus Streptomyces was conducted and the results represented that our strains belong to the Streptomyces genus (Fig. 3). The DNA sequences of all these endophytic actinomycetes were deposited in GenBank and accession numbers were obtained (Table 1).

\section{Anti-infective profiling}

The anti-infective potential of ethyl acetate fractions of endophytic actinomycetes was determined by disc diffusion assay (Fig. 4). All endophytic actinomycetes strains showed anti-microbial activity against the test human 


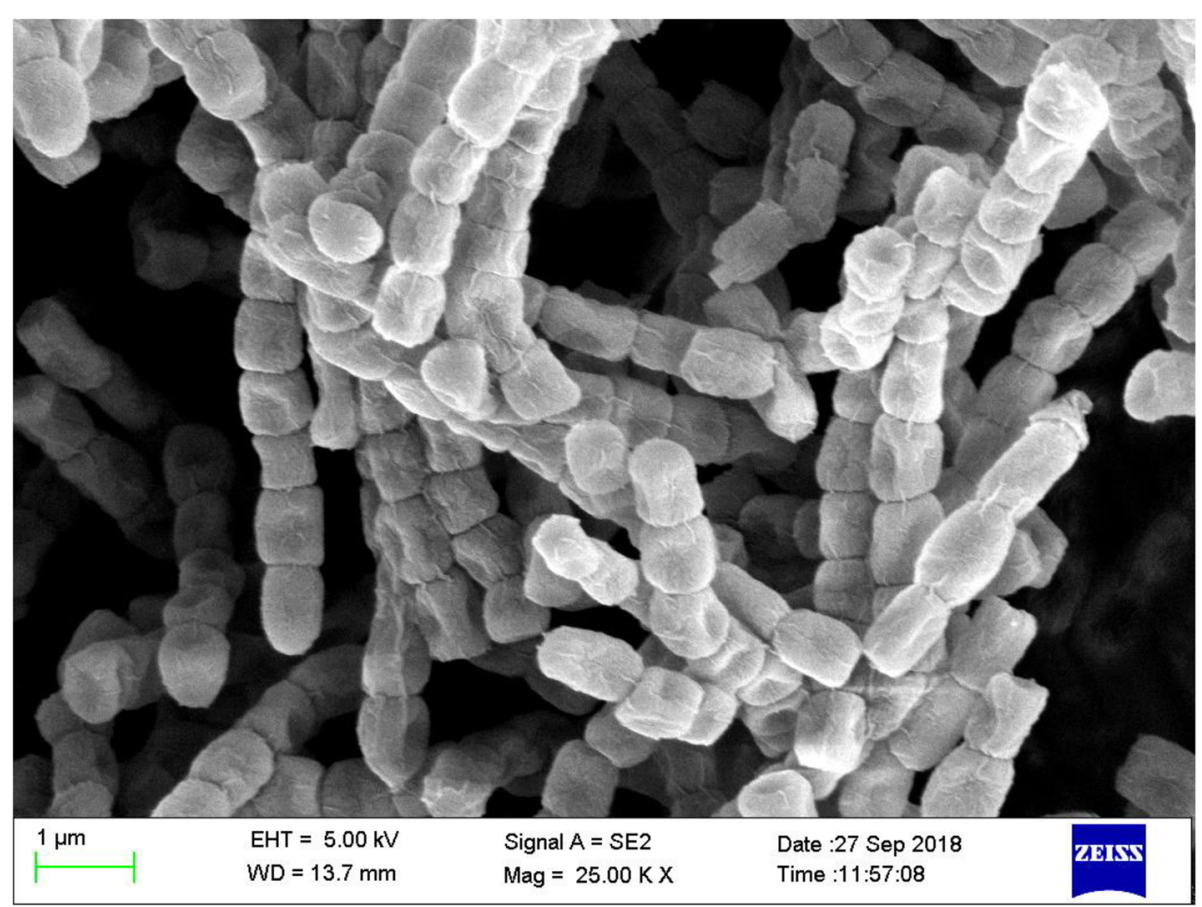

Fig. 2 Scanning electron micrograph showing spore ornamentation in Streptomyces sp. MI04

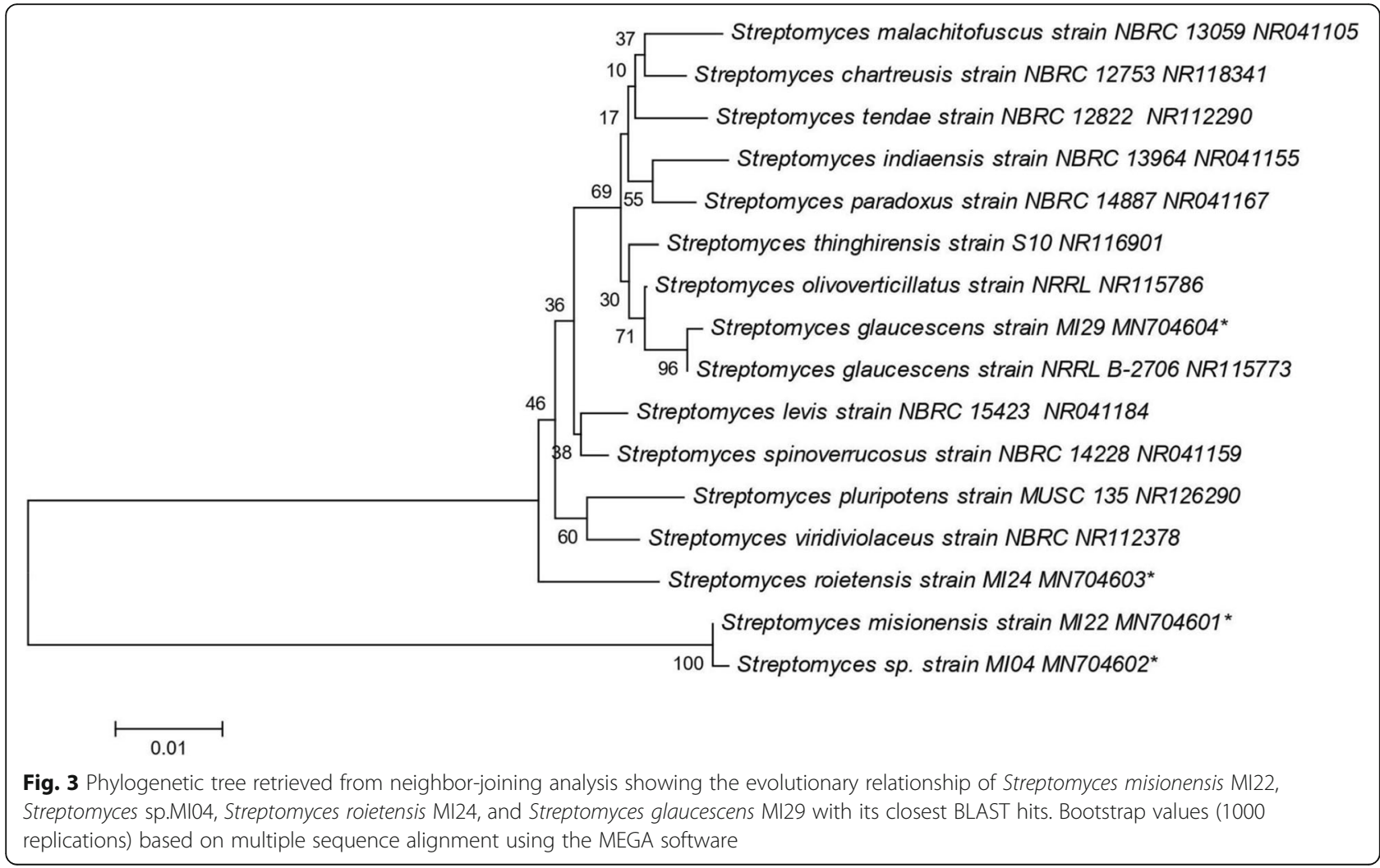


Table 1 List of endophytic actinomycetes strains isolated from Madhuca insignis with their morphological features and GenBank accession numbers

\begin{tabular}{|c|c|c|c|c|c|c|}
\hline Plant & $\begin{array}{l}\text { Plant } \\
\text { part }\end{array}$ & Place of collection & Media used & $\begin{array}{l}\text { Morphological } \\
\text { characteristics }\end{array}$ & Name of the isolate & $\begin{array}{l}\text { GenBank } \\
\text { accession } \\
\text { no. }\end{array}$ \\
\hline $\begin{array}{l}\text { Madhuca } \\
\text { insignis }\end{array}$ & Stem & $\begin{array}{l}\text { Agumbe } \\
\text { (Mangalore) }\end{array}$ & SCA & White colony & $\begin{array}{l}\text { Streptomyces } \\
\text { misionensisMI22 }\end{array}$ & MN704601 \\
\hline $\begin{array}{l}\text { Madhuca } \\
\text { insignis }\end{array}$ & Root & $\begin{array}{l}\text { Agumbe } \\
\text { (Mangalore) }\end{array}$ & ISP-2 & Creamy Whitish colony & Streptomyces sp.MI04 & MN704602 \\
\hline $\begin{array}{l}\text { Madhuca } \\
\text { insignis }\end{array}$ & Root & $\begin{array}{l}\text { Agumbe } \\
\text { (Mangalore) }\end{array}$ & SCA & Whitish powdery colony & Streptomyces roietensisMI24 & MN704603 \\
\hline $\begin{array}{l}\text { Madhuca } \\
\text { insignis }\end{array}$ & Leaf & $\begin{array}{l}\text { Agumbe } \\
\text { (Mangalore) }\end{array}$ & $\begin{array}{l}\text { Actinomycetes Isolation } \\
\text { Agar }\end{array}$ & Whitish colony & $\begin{array}{l}\text { Streptomyces } \\
\text { glaucescensMI29 }\end{array}$ & MN704604 \\
\hline
\end{tabular}

pathogens (Table 2). S. misionensis MI22 exhibited broad-spectrum significant anti-microbial activity against all the tested pathogens followed by $S$. glaucescens MI29, S. roietensis MI24, and Streptomyces sp. MI04. S. misionensis MI22 exhibited significant antimicrobial potential which depicted inhibition zones against MRSA, (25.00 $\pm 1.00 \mathrm{~mm})$, Escherichia coli $(22.00 \pm 0.00)$ Bacillus subtilis (23.66 $\pm 057 \mathrm{~mm})$ and Candida albicans $(18.00 \pm 0.00 \mathrm{~mm})$. The minimum inhibitory concentration test of ethyl acetate fractions showed potential anti-microbial activity ranging from
25 to $100 \mu \mathrm{g} / \mathrm{mL}$. The anti-microbial potential of these endophytic actinomycetes were compared with standard antibiotics (Table 3).

\section{Anti-proliferative activity}

The HeLa cells were treated with different concentrations of ethyl acetate fraction of S. misionensis MI22 ranged from 10 to $200 \mu \mathrm{g} / \mathrm{mL}$ to obtain $\mathrm{IC}_{50}$ value. Ethyl acetate fraction of strain MI22 exhibited significant growth inhibitory efficacy on $\mathrm{HeLa}$ cell line with $\mathrm{IC}_{50}$ value $98 \mu \mathrm{g} / \mathrm{mL}$. The cytotoxic potential of strain MI22

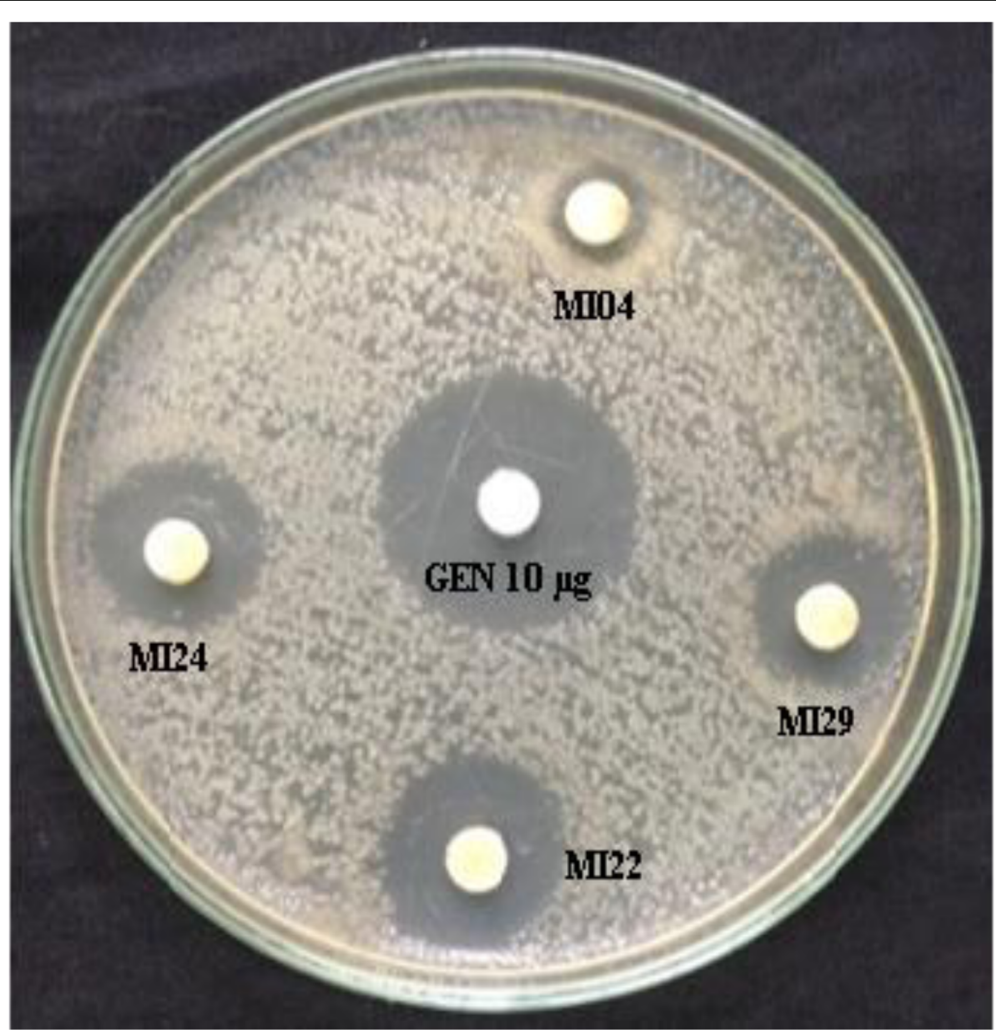

Fig. 4 Anti-microbial activity of ethyl acetate extract of Streptomyces strains against Methicillin-resistant Staphylococcus aureus by disc diffusion assay 
Table 2 Determination of anti-microbial activity of ethyl acetate extract of endophytic Streptomyces strains against test microbial pathogens

\begin{tabular}{lllll}
\hline Endophytic actinomycetes & \multicolumn{2}{l}{ Test pathogens } & & \\
\cline { 2 - 5 } & MRSA & Bacillus subtilis & Escherichia coli & Candida albicans \\
\hline Streptomyces misionensisMI22 & $25.00 \pm 1.00$ & $23.66 \pm 0.57$ & $22.00 \pm 0.00$ & $18.00 \pm 0.00$ \\
Streptomyces sp.MI04 & $12.33 \pm 0.57$ & $10.33 \pm 0.57$ & $19.00 \pm 0.00$ & $15.66 \pm 0.57$ \\
Streptomyces roietensisMI24 & $21.00 \pm 0.00$ & $21.00 \pm 0.00$ & $21.33 \pm 0.57$ & $17.33 \pm 0.57$ \\
Streptomyces glaucescensMI29 & $21.33 \pm 0.57$ & $21.66 \pm 0.57$ & $24.33 \pm 0.57$ & $20.33 \pm 0.57$ \\
Gentamicin (C) & $29.33 \pm 0.57$ & $31.00 \pm 0.00$ & $30.00 \pm 0.00$ & $\mathrm{ND}$ \\
Nystatin (C) & ND & ND & ND & $25.00 \pm 0.00$ \\
\hline
\end{tabular}

Value represents diameter of zone of inhibition in $\mathrm{mm}$ and data are means from 3 replicates $\pm \mathrm{SD}$. ND not determined, $\mathrm{C}$-positive control, Gentamicin $10 \mu \mathrm{g} /$ disc, Nystatin 100 units/disc

on the HEK293T cell line was turned to be negligible, indicating that crude extract was non-toxic to the noncancerous cell. The positive control curcumin was active at $60 \mu \mathrm{M}$ as the cells were reduced from $100 \%$.

\section{Thin layer chromatography-bioautography}

Ethyl acetate fraction of S. misionensis MI22 which showed anti-microbial activity was further tested in TLC-bioautography assay to detect the anti-microbial metabolites. TLC chromatographic profile showed the appearance of an intense band at $R_{f} 0.55$ under 254 and $365 \mathrm{~nm}$ (Fig. 5). The band appeared to be more intense which was due to the production of bioactive metabolites. A clear inhibition zone was observed on the same band in TLC bioautography where the medium was pre-inoculated with TTC agent and MRSA test pathogen.

\section{Discussion}

Actinomycetes represent a large taxonomic group in the Kingdom of bacteria and are wide spread in nature [39, 40]. Their high metabolic diversity makes them great potential candidates for the discovery and development of new drugs [41]. In fact, new antimicrobial metabolites produced by medicinal plants are increasingly being discovered and are always challenged by fluctuations in their environment and are vulnerable to diverse endophytic microbes. Endophytic actinomycetes inhabiting the medicinal plants located in the Western Ghats of India are well known to

Table 3 Minimum inhibitory concentration of ethyl acetate Streptomyces misionensis MI22 against test human pathogens

\begin{tabular}{ll}
\hline Test pathogens & MIC in $\boldsymbol{\mu g} / \mathbf{m l}$ \\
\hline Methicillin resistance Staphylococcus aureus & $25 \mu \mathrm{g} / \mathrm{ml}$ \\
Bacillus subtilis & $25 \mu \mathrm{g} / \mathrm{ml}$ \\
Escherichia coli & $50 \mu \mathrm{g} / \mathrm{ml}$ \\
Candida albicans & $100 \mu \mathrm{g} / \mathrm{ml}$ \\
\hline
\end{tabular}

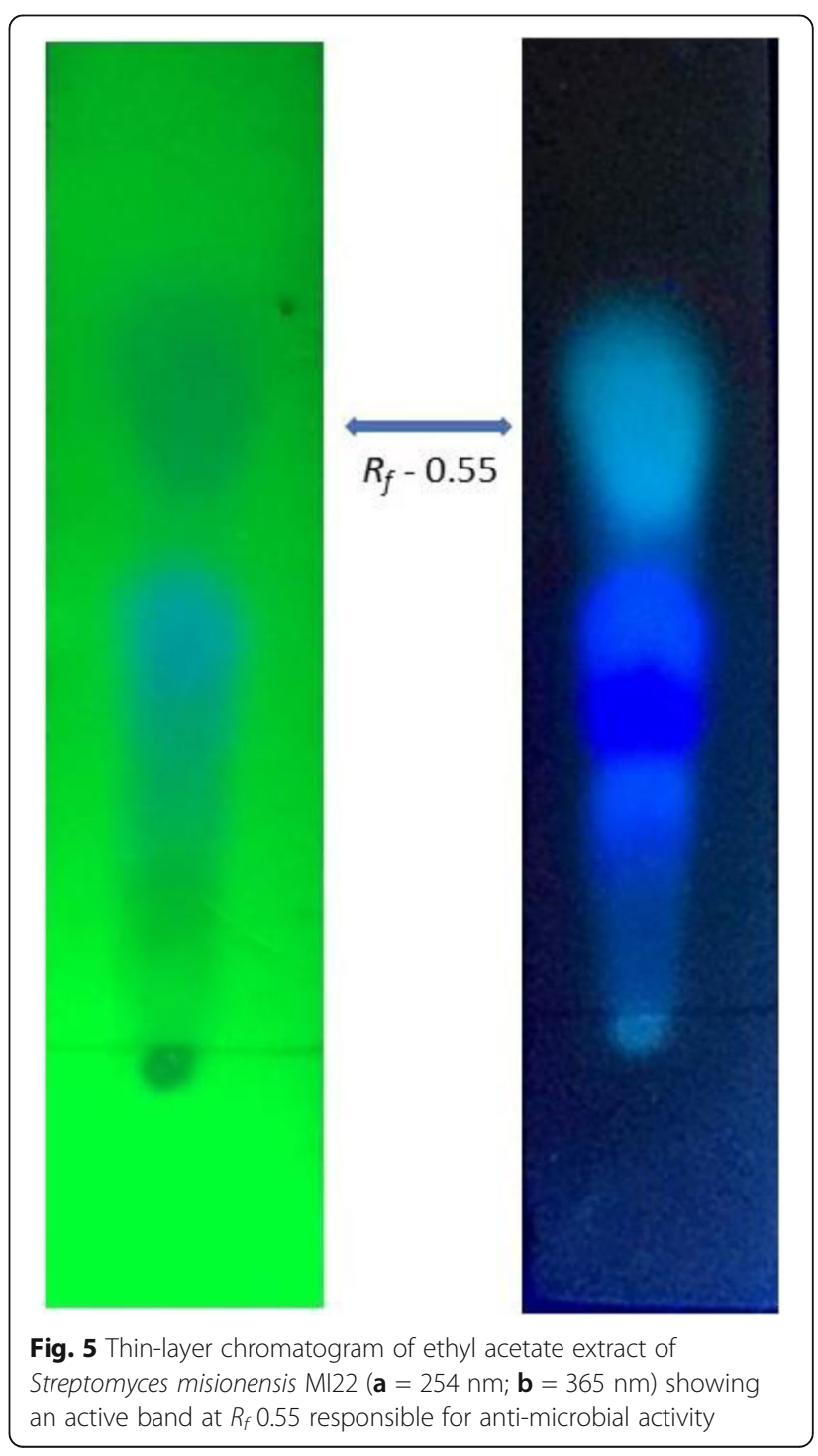


biosynthesize new biomolecules and our research implies that the Western Ghats of India has a great diversity of endophytic actinomycetes [42].

During the present research isolation of endophytic actinomycetes, Petri plates spread with a final rinse of sterile surface water did not indicate the growth of any microorganisms. Thus, confirming that the surface sterilization method was effective to remove epiphytic microorganisms and therefore this protocol is the best method to acquire true endophytes. This research work constitutes the first report on the incidence of endophytic actinomycetes from the medicinal plant Madhuca insignis. Four endophytic actinomycete isolates were selected to explore their anti-infective potential.

Examination of the endophytic actinomycetes isolates using their spore chain, morphology, colony surface, spiral sporophores, hyphe, filamentous nature, and other characteristic features helped for the preliminary identification. Many of the morphological characteristics observed from our strains are the characteristics of the genus Streptomycetes [43-46]. In the present study, we describe the taxonomic position of isolates together with phylogenetic and morphological characteristics. The conventional method to identify actinomycetes is by using microscopes. However, for detailed observations of spore structures of Streptomyces strains, scanning electron microscope is required to differentiate Streptomyces species based on spore surface, spore chain morphology, the formation of single spores and spore surface textures $[47,48]$. These morphological characters also have more significance in the modern era of Streptomyces taxonomy [49]. To support the reliability of morphological characterization, all strains were subjected to $16 \mathrm{~S}$ rRNA gene sequence analysis.

Molecular identification using 16S rRNA gene sequences is a cost-effective tool to identify complex microbial strains at species level. The phylogenetic analysis was executed for all four isolates using 16s rRNA gene sequences to identify at species level. The amplified gene sequenced was aligned with closely related strains sequences that recovered from NCBI database determined by BLAST search. A phylogenetic evaluation with related members of the genus Streptomyces was conducted and the results represented that our member belongs to Streptomyces genus. The phylogenetic neighbor-joining analysis showed that ours belonged to the members of Streptomyces misionensis strain MI22, Streptomyces roietensis strain MI24, Streptomyces glaucescens strain MI29, and Streptomyces sp. strain MI04. Thus, our strains identified as Streptomyces species with strong support. Many phylogenetical unidentified endophytic actinomycetes exist which might have great implications in drug discovery and development research.
Anti-microbial susceptibility of all strains was performed to manifest the bioactive secondary metabolites in ethyl acetate fractions. Ethyl acetate was used to extract the bioactive metabolites as most of the secondary metabolites are miscible with it [50]. Among all strains, S. misionensis MI22 exhibits a broad spectrum of antimicrobial activities which suggest their ability as a potent anti-microbial agent. The capability to inhibit both fungal and bacterial growth suggests that secondary biomolecules contain a wide spectrum of anti-microbial agents. Various earlier reports have described that extracts of endophytic actinomycetes culture have several medicinal properties [25, 51-53]. The genus Streptomyces have been proven to have anti-microbial activity suggesting that this Streptomyces genus is of great significance for the biodiscovery and research development of novel anti-infective drugs [23, 24]. Our research investigation is similar to earlier reports from Wang et al. [54], Li et al. [55], Jiang et al. [56], and Sharma and Thakur [57] who state that Streptomyces species inhabiting host plants have significant anti-microbial activity. The hunt for a new drug with diverse biological activities has benefitted more attention in recent years [58]. In this viewpoint, these potential endophytic actinomycetes are a prolific source to discover novel secondary metabolites.

Anti-microbial TLC bioautography assay was used to monitor anti-microbial metabolite detection. S. misionensis MI22 showed the appearance of an intense band that appeared at $R_{f} 0.55$ confirmed the presence of antimicrobial agents [59]. Identification of anti-infective compounds through TLC-bioautography assay is one of the best, consistent and easy techniques to discover drugs from the natural origin [60]. Further studies are required to identify the secondary biomolecules to resist against multi-drug resistant microorganisms and human pathogens for anti-bacterial activity. Tumor cell lines were susceptible to the crude extract drug suggesting their broad-spectrum of the anti-cancer potential of $S$. misionensis MI22. The minimal cytotoxic capability on non-cancerous cell lines indicates the drug safe for the isolation of anti-cancer metabolites of pharmaceutical interest.

Based on these outputs, further biological studies like anti-malarial, antioxidant, and chemical profiling of these potent metabolites are crucial to develop potential drugs. Clearly, advanced studies on the formulation and new technologies are important to employ them in the medical and agricultural areas. Exploring these endophytic actinomycetes to find out natural ways to discover new bioactive metabolites are fascinating in drug discovery research. This is one of the important concerns in drug discovery to address the present difficulty to human health in the areas of several metabolic disorders. 
In view of all these, endophytic S. misionensis MI22 is a potential source for future novel antibiotics.

\section{Conclusion}

This research indicates that targeting under-explored medicinal plants to explore hidden endophytic actinomycetes are a prolific source to discover new bioactive agents. S. misionensis MI22 as a potent source of bioactive drugs could help to fight against multidrugresistant infections. Further studies on the purification, identification of bioactive metabolites from $S$. misionensis MI22 and their other biological including preclinical trials is under process. The overall results suggest that these potential endophytic Streptomyces strains could be used for the production of bioactive metabolites for pharmaceutical applications.

\begin{abstract}
Abbreviations
NCBI: National Center of Biotechnology Information; ISP: International Streptomyces Project; PCR: Polymerase chain reaction; SCA: Starch casein agar; RF: Retention factor; DNA: Deoxyribonucleic acid; RNA: Ribonucleic acid; TTC: Triphenyl tetrazolium chloride; TLC: Thin layer chromatography; MTT: 1(4,5-Dimethylthiazol-2-yl)-3,5-diphenylformazan; MIC: Minimal inhibitory concentration; MRSA: Methicillin-resistant Staphylococcus aureus; BLAST: Basic Local Alignment Search Tool; MTCC: Microbial type culture collection; ATCC: American Type Culture Collection; HEK: Human embryonic kidney; DMSO: Dimethyl sulfoxide; ELISA: Enzyme-linked immunosorbent assay
\end{abstract}

\section{Acknowledgements}

Authors thank the Indian Council of Medical Research (ICMR), New Delhi, for the award of Senior Research Fellowship to the first author. We are grateful to the Centre for Nano Science and Engineering (CeNSE), the Indian Institute of Science, Bengaluru, for the scanning electron microscopic analysis. We also thank the Department of Studies in Microbiology, University of Mysore, for providing laboratory and instrumentation facilities.

\section{Authors' contributions}

VRR and SM designed the experiments. SM preformed the experiments. VRR and SM analyzed the data. SM wrote the manuscript. All authors have read and approved the final manuscript.

\section{Funding}

Indian Council of Medical Research (ICMR), New Delhi in the form of Senior Research Fellowship (No. 3/2/2/65/2018/Online OncoFship/NCD-III) to the first author. The funder has no role in the study.

\section{Availability of data and materials}

All data generated or analyzed during this study are included in this published article.

Ethics approval and consent to participate

Not applicable

\section{Consent for publication}

Not applicable

\section{Competing interests}

The authors declare that they have no competing interests.

Received: 30 September 2020 Accepted: 15 February 2021 Published online: 24 February 2021

\section{References}

1. Mukherjee S (2017) Emerging infectious diseases: epidemiological perspective. Indian J Dermatol 62(5):459
2. Ramshaw RE, Letourneau ID, Hong AY, Hon J, Morgan JD, Osborne JC, Shirude S, Van Kerkhove MD, Hay SI, Pigott DM (2019) A database of geopositioned middle east respiratory syndrome coronavirus occurrences. Sci Data 6:318

3. Baltz RH, Katz L (2016) Natural product discovery: past, present, and future. J Microbiol Biotechnol 43(2-3):155-176

4. Newman DJ, Cragg GM (2020) Natural products as sources of new drugs over the nearly four decades from 01/1981 to 09/2019. J Nat Prod 83(3): 770-803

5. Gupte S, Kaur M, Kaur M (2017) Novel approaches to developing new antibiotics. J Bacteriol Mycol Open Access 4:00089

6. Houbraken J, Frisvad JC, Samson RA (2011) Fleming's penicillin producing strain is not Penicillium chrysogenum but $P$. rubens. IMA Fungus 2(1):87-95

7. Staniek A, Woerdenbag HJ, Kayser O (2008) Endophytes: exploiting biodiversity for the improvement of natural product based drug discovery. J Plant Interact 3:75-98

8. Rai M, Rathod D, Agarkar G, Dar M, Brestic M, Marostica Junior MR (2014) Fungal growth promoter endophytes: a pragmatic approach towards sustainable food and agriculture. Symbiosis 62:63-79

9. Mitchell AM, Strobel GA, Moore E, Robison R, Sears J (2010) Volatile antimicrobials from Muscodor crispans, a novel endophytic fungus. Microbiology 156:270-277

10. Kumar A, Patil D, Rajamohanan PR, Ahmad A (2013) Isolation, purification and characterization of from endophytic fungus Fusarium oxysporum isolated from Catharanthus roseus. PLOS ONE 8(9):e71805

11. Chithra S, Jasima B, Sachidanandan P, Jyothisa M, Radhakrishnan EK (2014) Piperine production by endophytic fungus Colletotrichum gloeosporioides isolated from Piper nigrum. Phytomed 21:534-540

12. Deepika VB, Murali TS, Satyamoorthy K (2016) Modulation of genetic clusters for the synthesis of bioactive molecules in fungal endophytes: A review. Microbiol Res 182:125-140

13. Hou BC, Wang ET, Li Y, Jia RZ, Chen WF, Man CX, Sui XH, Chen WX (2009) Rhizobial resource associated with epidemic legumes in Tibet. Microb Ecol 57(1):69-81

14. Li J, Zhao GZ, Chen HH, Wang HB, Qin S, Zhu WY, Xu LH, Jiang CL, Li WJ (2008) Antitumour and antimicrobial activities of endophytic Streptomycetes from pharmaceutical plants in rain forest. Lett Appl Microbiol 47(6):574-580

15. Bascom-Slack CA, Ma C, Moore E, Babbs B, Fenn K, Greene JS, Hann BD, Keehner J, Kelley-Swift EG, Kembaiyan V, Lee SJ, Li P, Light DY, Lin EH, Schorn MA, Vekhter D, Boulanger LA, Hess WM, Vargas PN, Strobel GA, Strobel SA (2009) Multiple, novel biologically active endophytic actinomycetes isolated from upper Amazonian rainforests. Microb Ecol 58(2):374-383

16. Qin S, Xing K, Jiang JH, Xu LH, Li WJ (2011) Biodiversity, bioactive natural products and biotechnological potential of plant-associated endophytic actinobacteria. Appl Microbiol Biotechnol 89(3):457-473

17. Thumar JT, Dhulia K, Singh SP (2010) Isolation and partial purification of an antimicrobial agent from halotolerant alkaliphilic Streptomyces aburaviensis strain Kut-8. World J Microbiol Biotechnol 26:2081-2087

18. Wang C, Wang Z, Qiao X, Li Z, Li F, Chen M, Wang Y, Huang Y, Cui (2013) Antifungal activity of volatile organic compounds from Streptomyces alboflavus TD-1. FEMS Microbiol Lett 34:45-51

19. Tiwari K., Gupta RK (2014) Studies in natural products chemistry. bioactive metabolites from rare actinomycetes; Elsevier: New York, NY, USA, Chapter 14

20. Managamuri U, Vijayalakshmi M, Ganduri VSRK, Rajulapati SB,Bonigala B, Kalyani BS, Poda S (2017) Isolation, identification,optimization, and metabolite profiling of Streptomyces sparsus VSM-30. 3Biotech 7:217

21. Vurukonda SSKP, Giovanardi D, Stefani E (2018) Plant growth promoting and biocontrol activity of Streptomyces spp. as endophytes. Int J Mol Sci 19: 952

22. Barka EA, Vatsa P, Sanchez L, Vaillant NG, Jacquard C, Klenk HP, Clement C, Ouhdouch Y, Wezel GPV (2016) Taxonomy, physiology, and natural products of Actinobacteria. Microbiol Mol Biol Rev 80:1-43

23. Robertsen HL, Weber T, Kim HU, Lee SY (2017) Towards systems metabolic engineering of Streptomycetes for secondary metabolites production. Biotechnol J 13:27

24. Shan W, Zhou Y, Liu H, Yu X (2018) Endophytic actinomycetes from tea plants (Camellia sinensis): isolation, abundance, antimicrobial, and plantgrowth-promoting activities. Bio Med Res Int 2:1-12

25. Mondal S, Rai VR (2019) Molecular profiling of endophytic Streptomyces cavourensis MH16 inhabiting Millingtonia hortensis Linn. and influence of 
different culture media on the biosynthesis of antimicrobial metabolites. Sci Nat 106:51

26. Kumar GK, Shenoy HS, Kaveriappa KM (2004) Rediscovery of Madhuca insignis (Radlkofer) H.J.Lam (Sapotaceae) - A critically endangered species of the Western Ghats, India. Phytomorphology 54(3 \& 4):209-213

27. Udayan PS (2004) A new location for Madhuca insignis (Radlk.) H.J.Lam.-A rare, endemicand red listed plant near Venur of Dakshin Kannada district, Karnataka. Sliva's Newletter, p 295

28. Ravikumar K, Sankar RV, Ved DK, Bhat KG (2004) Is Madhuca insignis (Radlk) H.J.Lam (Sapotaceae) really extinct? Phytotaxonomy 4:119-123

29. Raveendran K (2013) Madhuca insignis (Radlk.) H.J.Lam. (Sapotaceae) -new addition to the flora of Kerala. Zoo's PRINT 28(4):25-26

30. Shenoy HS, Rajasekharan PE, Souravi K, Anand M (2014) Extended distribution of Madhuca insignis (Radlk.) H.J. Lam. (Sapotaceae) -A critically endangered species in Shimoga district of Karnataka. Zoo's Print Journal, XXIX (6): 21-23

31. Gill S, Panthari P, Kharkwal H (2015) Phytochemical investigation of high altitude medicinal plants Cinnamomum tamala (buch-ham) nees and eberm and Rhododendron arboreum Smith. Am J Phytomed Clin Ther 3(6):512-528

32. Yan XC (2013) Isolation and identification of actinomycete. Science Beijing: 45-68

33. Heuer H, Krsek M, Baker P, Smalla K, Wellington EM (1997) Analysis of actinomycete communities by specific amplification of genes encoding 165 rRNA and gel electrophoretic separation in denaturing gradients. Appl Environ Microbiol 63:3233-3241

34. Padhi S, Tayung K (2013) Antimicrobial activity and molecular characterization of an endophytic fungus Quambalaria sp. isolated from Ipomoea carnea. Ann Microbiol 63:793-800

35. Anibou M, Zyadi A, Chait A, Benharref A, Ouhdouch Y (2008) Actinomycetes from Moroccan habitats: isolation and screening for cytotoxic activities. World J Microbiol Biotechnol 24(10):2019-2025

36. Clinical and Laboratory Standards Institute (CLSI) (2009) Performance standards for antimicrobial disk susceptibility tests; approved standard, 10th Ed. M02-A10.CLSI, Wayne, PA, USA

37. Ramesh N, Mathivanan (2009) Screening of marine actinomycetes isolated from the Bay of Bengal, India for antimicrobial activity and industrial enzymes. World J Microbiol Biotechnol 25:2103-2111

38. Valgas C, Souza SMD, Smania EF, Smania JA (2007) Screening methods to determine antibacterial activity of natural products. Braz J Microbiol 38:369380

39. Paredes SH, Gao T, Law TF, Finkel OM, Mucyn T, Teixeira PJPL, Gonzalez IS, Feltcher ME, Power MJ, Shank EA, Jones CD, Jojic V (2018) Design of synthetic bacterial communities for predictable plant phenotypes. PLoS Biol 16(2):e2003962

40. Dinesh R, Anandaraj M, Kumar A, Bini YK, Subila KP, Aravind R (2015) Isolation, characterization, and evaluation of multi-trait plant growth promoting rhizobacteria for their growth promoting and disease suppressing effects on ginger. Microbiol Res 173:34-43

41. Zhang Z, Tang W (2018) Drug metabolism in drug discovery and development. Acta Pharma Sin B 8(5):721-732

42. TaechowisanT PJF, Lumyong S (2003) Isolation of endophytic actinomycetes from selected plants and their antifungal activity. World J Microb Biot 19: 381-385

43. Shirling EB, Gottlieb D (1966) Methods for characterization of Streptomyces species. Int J Syst Bacteriol 16:313-340

44. Kornerup A, Wanscher JH (1978) Methuen handbook of colour, 3rd edn. Methuen, London

45. Sujatha P, Raju K, Ramana T (2005) Studies on a new marine Streptomycete BT-408 producing polyketide antibiotic SBR-22 effective against methicillin resistant Staphylococcus aureus. Microbiol Res 160:119-126

46. Kumar KS, Haritha R, Mohan YSYVJ, Ramana T (2011) Screening of marine actinobacteria for antimicrobial compounds. Res J Microbiol 6:385-393

47. Williams ST, Davies FL (1967) Use of a scanning electron microscope for the examination of actinomycetes. J Gen Microbiol 48:171-177

48. Castillo U, Myers S, Bwone L, Strobel G, Hess WM, Hanks J, Reay D (2006) Scanning electron microscopy of some endophytic Streptomycetes in Snake vine-Kennedia niggricans. Scannings 27:305-311

49. Tresner HD, Davies MV, Backus EJ (1961) Electron microscopy of Streptomyces spore morphology and its role in species differentiation. J Bacteriol 81:70-80
50. Jumpathong J, Seshime J, Fujii Y, Peberdy JF, Lumyong S (2011) Genome screening for reducing type I polyketide synthase genes in tropical fungi associated with medicinal plants. World J Microbiol Biotechnol 27:19891995

51. Verma VC, Gond SK, Kumar A, Mishra A, Kharwar RN, Gange AC (2009) Endophytic actinomycetes from Azadirachta indica A. Juss: isolation, diversity, and anti-microbial activity. Microb Ecol 57:749-756

52. Rajivgandhi G, Vijayan R, Kannan M, Santhanakrishnan M, Manoharan N (2016) Molecular characterization and antibacterial effect of endophytic actinomycetes Nocardiopsis sp. GRG1 (KT235640) from brown algae against MDR strains of uropathogens. Bioactive Materials 1(2):140-150

53. Musa Z, Ma J, Egamberdieva D, Mohamad OA, Abaydulla G, Liu Y, Li WJ, Li L (2020) Diversity and antimicrobial potential of cultivable endophytic actinobacteria associated with the medicinal plant Thymus roseus. Front Microbiol 11:191

54. Wang L, Qiu P, Long XF, Zhang S, Zeng ZG (2016) Comparative analysis of chemical constituents, antimicrobial and antioxidant activities of ethyl acetate extracts of Polygonum cuspidatum and its endophytic actinomycete, Streptomyces sp. A0916. Chin J Nat Med 14:117-123

55. Li X, Huang P, Wang Q, Xiao L, Liu M, Bolla K. Zhang B, Zheng L, Gan B, Liu $X$, Zhang L, Zhang X (2014) Staurosporine from the endophytic Streptomyces sp. strain CNS-42 acts as a potential biocontrol agent and growth elicitor in cucumber. Antonie Van Leeuwenhoek 106:515-525

56. Jiang ZK, Tuo L, Huang DL, Osterman IA, Tyurin AP, Liu SW, Lukyanov DA, Sergiev PV, Dontsova OA, Korshun VA, Li FN, Sun CH (2018) Diversity, novelty, and antimicrobial activity of endophytic actinobacteria from mangrove plants in Beilun estuary national nature reserve of Guangxi China. Front Microbiol 9:868

57. Sharma P, Thakur D (2020) Antimicrobial biosynthetic potential and diversity of culturable soil actinobacteria from forest ecosystems of Northeast India. Scientific Reports 10(1):1-8

58. Dharmaraj S (2011) Antagonistic potential of marine actinobacteria against fish and shellfish pathogens. Turk J Biol 35:303-311

59. Hota D (2010) Evaluation of plant extracts. Bioactive medicinal plants. GeneTech Books New Delhi, In, pp 86-87

60. Patra JK, Gouda S, Sahoo SK, Thatoi HN (2012) Chromatography separation, 1 H NMR analysis and bioautography screening of methanol extract of Excoecaria agallocha L. from Bhitarkanika, Orissa, India. Asian Pac J Trop Biomed 2(1):S50-SS5

\section{Publisher's Note}

Springer Nature remains neutral with regard to jurisdictional claims in published maps and institutional affiliations.

\section{Submit your manuscript to a SpringerOpen ${ }^{\circ}$ journal and benefit from:}

- Convenient online submission

- Rigorous peer review

- Open access: articles freely available online

- High visibility within the field

- Retaining the copyright to your article

Submit your next manuscript at $\boldsymbol{\nabla}$ springeropen.com 